\title{
PRECARIOUS SETTLEMENTS IN A REGIONAL METROPOLIS OF NORTHEAST BRAZIL: THE CASE OF THE FORTALEZA CITY, CEARÁ STATE
}

\author{
João Sérgio Queiroz de Lima \\ Universidade Federal do Ceará, Departamento de Geografia, Fortaleza, CE, Brasil \\ joaosergio1980@gmail.com \\ Jader de Oliveira Santos \\ Universidade Federal do Ceará, Departamento de Geografia, Fortaleza, CE, Brasil \\ jader.santos@gmail.com
}

\begin{abstract}
Housing problems in the world have resulted in precarious settlements in urban territories. In Brazil, these settlements reached $30 \%$ of urban homes at the beginning of the 21 st century. The objective of this article is to recognize the situation of the settlements in the city of Fortaleza, capital of the Ceará State-Brazil, from the identification, spatialization, classification of typologies and demographic characterization. An integrative method is used for the systematization of georeferenced data in the Geographic Information System (GIS) and thematic mapping. Were identified 838 precarious settlements in the city, composed of 29 tenements, 16 irregular allotments, 48 housing estates, 128 community housing projects and 617 shanty-towns, with 352,597 families, 243,180 dwellings and 964,562 inhabitants. They represent $34 \%$ of the properties, $39.34 \%$ of the population and $19.19 \%$ of the territory, in areas with poor infrastructure, services and urban equipment, inhabited by the lower income population. The study provides the analytical basis of vulnerability to environmental disasters and potentiates discussion of urban space issues.
\end{abstract}

Key words: Precarious settlements. Shanty-towns. Urban site. Brazilian Fortaleza City. Geographic Information System.

\section{ASSENTAMENTOS PRECÁRIOS EM UMA METRÓPOLIS REGIONAL DO NORDESTE DO BRASIL: O CASO DA CIDADE FORTALEZA, ESTADO DO CEARÁ}

\begin{abstract}
RESUMO
Os problemas habitacionais no mundo resultaram nos assentamentos precários nos territórios urbanos. No Brasil, esses assentamentos alcançaram 30\% dos domicílios urbanos no início do século XXI. O objetivo deste artigo é reconhecer a situação dos assentamentos na Cidade de Fortaleza, capital do Estado do Ceará-Brasil, através da identificação, espacialização, classificação das tipologias e caracterização demográfica. Utiliza-se método integrativo para sistematização de dados georreferenciados em Sistema de Informações Geográficas (SIG) e mapeamento temático. Foram identificados 838 assentamentos precários na cidade, sendo 29 cortiços, 16 loteamentos, 48 conjuntos habitacionais, 128 mutirões e 617 favelas, com 352.597 famílias, 243.180 imóveis e 964.562 habitantes. Representam 34\% dos imóveis, 39,34\% da população e 19,19\% do território, em áreas com déficit de infraestruturas, serviços e equipamentos urbanos, habitadas pela população de menor renda. O estudo oferece a base analítica da vulnerabilidade aos desastres ambientais e potencializa discussão das problemáticas sobre o espaço urbano.
\end{abstract}

Palavras-chave: Assentamentos precários. Favelas. Sítio urbano. Cidade de Fortaleza. Sistema de Informações Geográficas.

\section{INTRODUCTION}

Precarious settlements are often adopted as solution for the housing shortages found in the developing world, although they tend to create additional problems through the lack of planning, the unregulated occupation of urban environments, and inadequate construction practices. In addition to the multiplication of social problems, the risk of environmental disasters increases considerably.

Correa (1999) and Rodrigues (2016) consider housing to be a form of merchandise that associates properties with land urbanized through the establishment of services and infrastructure. This results in high prices, which

$\begin{array}{llllll}\text { Caminhos de Geografia } & \text { Uberlândia - MG } & \text { v. 19, n. } 67 & \text { Set/2018 } & \text { p. 289-303 Página } 289\end{array}$


limit the access of a majority of the population, leading to social exclusion. In this context, precarious settlement has traditionally provided housing to the sector of the population unable to access the formal property market or housing programs in developing countries, especially in Latin America and Brazil, where it composes a large part of the urban landscape.

At the present time, more than a billion people, worldwide, live in precarious urban settlements, a number expected to reach two billion over the next 30 years. In industrialized developing countries, $40 \%$ of the urban population lives in precarious conditions. In Latin America and the Caribbean, this represents 128 million inhabitants (UN-HABITAT, 2012).

At the beginning of the 21st Century, this type of housing accounts for $30 \%$ of the urban residences in Brazil, encompassing a total of 3.2 million precarious households, including shanty-towns, slums, and irregular allotments (BRASIL, 2010b). The urban population of Brazil grew exponentially between 1940 and 1980 (SANTOS, 2008). In the 1960s, the country's population shifted from a predominantly rural configuration to an urban one, with urbanization predominating from the 1970s onwards. In the 1980s, the relative growth of the urban population exceeded that of the country's total population, and in the 1990s, urbanization accelerated even further, and became consolidated throughout the country.

At the turn of the 20th Century, $82 \%$ of the population of Brazil inhabited the urban zone, resulting in profound social problems, such as unemployment, the informal economy, social exclusion, and socio-spatial segregation, with profound implications for the living conditions of the majority of society. This situation, characterized by the increasing precariousness of housing in the cities, resulting from the accelerating urbanization of the Brazilian metropolises, is permeated by social inequalities and marked socio-spatial segregation of the low-income population. Which culminates in an urban periphery, characterized by its illegality, and the profound irregularity and instability of its urban planning and construction.

The widespread control of industrial development, the construction industry, and real estate interests by large corporations, with the support of the state government, results in the accumulation of capital and determines the formation of the urban landscape (COSTA, 1978). CARLOS (2015) concluded that the urban structure reflects collective urban problems, privatizing the benefits, while socializing the costs of the urbanization process. This results in social fragmentation, and the residential segregation of the cities (SOJA, 1993).

Social classes are reflected in their differential access to housing and commercial facilities, which CARLOS (2015) identifies as the hallmark of spatial segregation. This contributes to urban problems in Brazil, and in particular the housing shortage, which reached 6.5 million units in 2010 , corresponding to approximately $12 \%$ of all Brazilian households (BRASIL, 2010a).

Compounding these problems, 3905 shanty-towns were found in Brazil at the beginning of the 20th Century. In 2010, there were 6329 shanty-towns in the country, with a total population of 11,425,644 inhabitants, the equivalent of $6 \%$ of the population of Brazil (BRASIL, 2001, 2011). The country's precarious settlements also include tenements, irregular allotments in peripheral zones, and degraded housing estates.

In this problematic national panorama, the situation of the city of Fortaleza deserves attention, with $16.2 \%$ of its population in 2010 occupying subnormal settlements, accordion to IBGE (BRASIL, 2011). In study (FUNDAÇÃO JOÃO PINHEIRO, 2013) commissioned by the Brazilian Ministry for Cities recorded 3031 precarious households in Fortaleza (3.2\% of the total in the city) and 199,125 residences (28\% of the total) that lacked adequate urban infrastructure. There is a deficit of 95,166 residences $(13.4 \%$ of the properties in the city).

The Northeastern regional metropolis follows the panorama of the largest cities in the country, marked by strong socio-spatial segregation, caused by enormous income disparities, which have a wide differentiation in the quality of infrastructure, services and housing standards between neighborhoods and communities. $\mathrm{He}$ housing undertaken in a precarious, though problematic, way is a solution for a large part of the low-income population in Fortaleza, generated by the high and growing housing deficit.Pequeno (2008) and Silva (2009), point out the growing commercialization of urban land and housing rooted at the beginning of the 21st century, and the insufficiency of popular housing policies, have led to a high housing deficit, contributing significantly to the expansion of the precarious settlements.

In the institutional context, the lack of organized information about the precariousness of housing in the cities has led the municipal government to the preparation of the Local Plan of Housing of Social Interest of Fortaleza (PLHISFor) in 2012. The document presented an important summary of the housing problems in the city, aiming to subsidize the planning of public policies. However, there is a need to revise the information, especially regarding the compatibility with the spatial reality in the present days. 
The geographic study of these processes on an urban scale should involve the understanding of the material form of the city, and its physical-spatial dynamics (MARTINS, 2006). In this context, the present study aimed to understand the current situation of the precarious settlements in the urban setting of the Fortaleza City as a baseline for the analysis of the communities occupying areas vulnerable to environmental disasters through the definition of their spatial distribution, the production of thematic maps, and quantitative and demographic diagnoses. For this, it was necessary to collect, store, process, and analyze data for the presentation of spatial parameters. The results of this survey represent an overview of the precarious settlements of Fortaleza at the beginning of the 21st Century, up until 2010, including a classification of the principal types of settlement, quantitative parameters, demographic features, and the territorial configuration of the municipality.

These urban settlements are known to be relatively vulnerable to environmental disasters, and should be prioritized in urban planning policies aimed at the prevention of risks through urbanization and redevelopment. This situation reinforces the need for further scientific research integrating socio-economic and physical and natural sciences in a holistic approach, such as those developed by Santos and Ross (2012) and Santos (2015).

\section{Background}

A precarious urban settlement (Table 1 and Figure 1) is defined here as an ensemble of buildings constructed irregularly, illegally and inadequately, used primarily for housing, with a distinct social and community identity in comparison with the rest of the urban landscape. The principal productive agents of these settlements are low-income social groups, which adopt alternative strategies in comparison with the formal property market (PEQUENO, 2008; MARICATO, 2009).

Table 1: Types of precarious settlement

\begin{tabular}{|c|c|}
\hline $\begin{array}{c}\text { Type of } \\
\text { settlement }\end{array}$ & Characteristics \\
\hline Shanty-town & $\begin{array}{l}\text { Spontaneous occupation. Irregular and precarious street layout and occupation pattern, } \\
\text { which is distinct from the formal infrastructure of the city. Built-up area almost } \\
\text { continuous, with closely-spaced households connected by narrow walkways. When } \\
\text { occupied by organized housing movements, the street layout may be pre-planned, with } \\
\text { established plots, as in the case of the unregulated housing estates. Living conditions } \\
\text { vary considerably within the same shanty-town, and may include relatively good quality } \\
\text { housing on streets with regular vehicular traffic, typically in areas adjacent to the regular } \\
\text { city. The quality of the housing tends to decline towards the center of the settlements, } \\
\text { often where less suitable environmental conditions are found, such as steep slopes and } \\
\text { the margins of bodies of water. }\end{array}$ \\
\hline Tenement & $\begin{array}{l}\text { Most tenements are located in central areas. They are rented properties, and are } \\
\text { typically located in underutilized properties. A precise record can only be obtained from } \\
\text { a field survey. This type of residence can be found within the shanty-town and } \\
\text { peripheral slums, and other types of settlement, becoming an integrated part of the } \\
\text { settlement, which makes research difficult. }\end{array}$ \\
\hline $\begin{array}{l}\text { Irregular } \\
\text { allotment }\end{array}$ & $\begin{array}{c}\text { These settlements have a more regular layout, with better access in comparison with } \\
\text { the shanty-towns, and well-defined plots. The areas destined for the implantation of } \\
\text { public buildings and parks are generally occupied by shanty-towns, hampering the } \\
\text { legalization of the properties, and impeding the access of other residents to these } \\
\text { public amenities. In many cases, the land has been occupied illegally through } \\
\text { organized occupations. }\end{array}$ \\
\hline $\begin{array}{l}\text { Degraded } \\
\text { and } \\
\text { unregulated } \\
\text { housing } \\
\text { estate }\end{array}$ & $\begin{array}{l}\text { Produced by public entities through specific investments for the establishment of social } \\
\text { programs. In most cases, the properties have not been legalized in the name of the } \\
\text { resident family that benefitted from the housing program. One other factor determining } \\
\text { the precarious nature of these estates is the degradation of the buildings, which are } \\
\text { typically old and lack regular maintenance. Degradation is not universal, however, } \\
\text { especially where the property has a relatively good market value. }\end{array}$ \\
\hline $\begin{array}{l}\text { Community } \\
\text { housing } \\
\text { project }\end{array}$ & $\begin{array}{l}\text { Fragmented housing estates, consisting of single-family units built by social housing } \\
\text { programs. The public institution provides the architectural project, building materials, } \\
\text { and a public sanitation system. The families selected for the program are responsible } \\
\text { for the construction of the buildings. The program does not have urban planning or } \\
\text { property rights, however. In some cases, the families have constructed their housing in } \\
\text { areas of environmental risk. }\end{array}$ \\
\hline
\end{tabular}

Sources: Correa (1999), Maricato (2003), Pequeno (2008), Souza (2009) and Silva (2009). Organization: the authors. 
Figure 1: The City of Fortaleza: spatial aspects and typologies of precarious settlements 1.

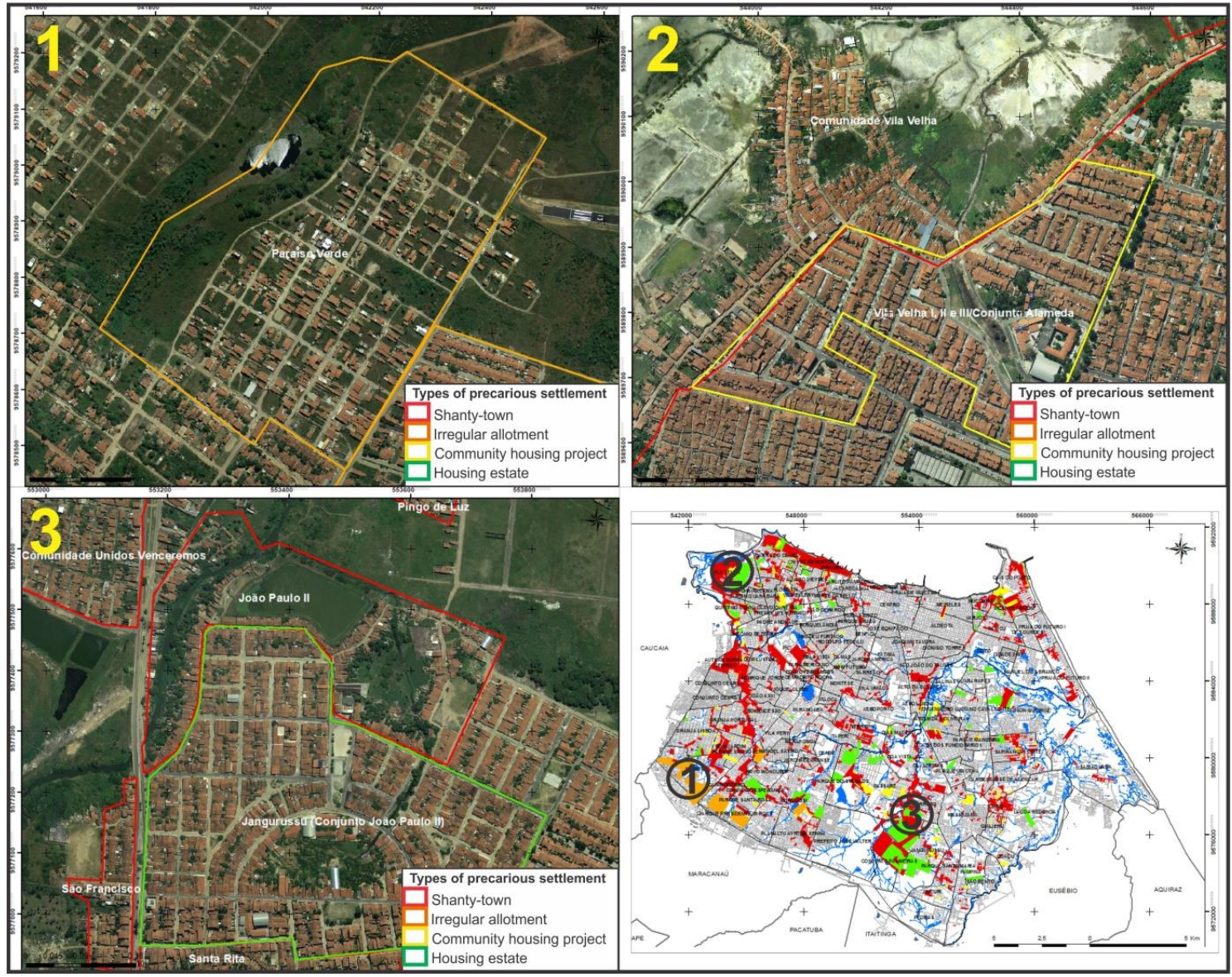

Source: authors. Note: 1 - Paraíso Verde irregular allotment, in the Siqueira nighborhood; 2. Mutirão Habitacional Conjunto Alameda and community favela Vila Velha, in the Vila Velha neighborhood; 3. Degraded housing complex John Paul II and favelas São Francisco, John Paul II and Comunidade Unidos Venceremos, in the Barroso neighborhood.

The precarious settlements are closely related to irregular property registration. Normally, the residents are not the legal owners of the properties they occupy, whether individually or collectively. These settlements are established spontaneously, with no systematic planning, and their illegality being reinforced by the widespread disrespect for building regulations and municipal legislation (construction, urban or environmental) in the urban landscape.

The physical conditions, architecture, and urban infrastructure of precarious settlements are extremely inadequate and degraded. The conditions are characterized by a lack of comfort and their insalubrity, and a lack of access to essential public services. The high population density is a result of the small size of the properties, combined with the typically large size of the resident families, and the fact that properties are often inhabited by more than one family. The high density of properties also reduces mobility and accessibility.

The resident populations of these settlements are characterized by fundamental social problems, such as low incomes, reduced access to good quality education and public health services, and a general lack of social services. The population is highly vulnerable due to the reduced resilience of the social groups. The principal threats include poverty, violence, epidemics, and environmental disasters.

The Brazilian Ministry for Cities defines precarious settlements in terms of the inadequacies of the formal urban context. These inadequacies include problems with property registration, urban planning, construction codes, and environmental legislation, all of which are associated with low incomes (BRASIL, 2004). 
The UN-Habitat program (2003) uses the term "slum" to refer to a number of different types of precarious settlement, as the most visible manifestation of urban poverty in developing countries, with the precariousness of these settlements being derived from their limited access to adequate public sanitation, the low quality of the constructions, overpopulation, and the insecurity derived from unpredictable and arbitrary evictions. In Brazil that the problem is typically urban, and is derived from the low income of the populations that inhabit these areas, which are characterized by unregulated properties, high population densities, a lack of infrastructure and urban services, as well as substandard living conditions, which reinforce the need for the intervention of public authorities.

Precarious settlements encompass, concentrate, and potentialize a wide range of irregularities and precariousness, enhancing the vulnerability, and social and environmental risks of these segregated communities. These conditions are the result of poverty, social and spatial inequalities, precarious housing, and urban irregularities.

\section{Study area}

The Fortaleza City is the capital of the Brazilian state of Ceará, with a metropolitan region that includes 19 municipalities. This region encompasses much of the economic infrastructure of Ceará, and $29.03 \%$ of the state's population. Fortaleza is the largest urban center of the northern coast of the Brazilian Northeast region. In 2010 , the city had a population of $2,452,185$ inhabitants, the fifth largest in Brazil (BRASIL, 2011).

The municipality of Fortaleza has a total area of $314,9 \mathrm{~km}^{2}$, and is located on the northern coast of the Brazilian Northeast region ( $3^{\circ} 45^{\prime} 47^{\prime \prime} \mathrm{S}, 3^{\circ} 32^{\prime} 35^{\prime \prime} \mathrm{W}$ ), in the north of the state of Ceará (Figure 2). It is limited to the north by the Atlantic Ocean, to the south by the municipalities of Maracanaú, Itaitinga and Pacatuba, to the west by Eusébio and Aquiraz, and to the east, by the municipality of Caucaia.

Figure 2: Study site.

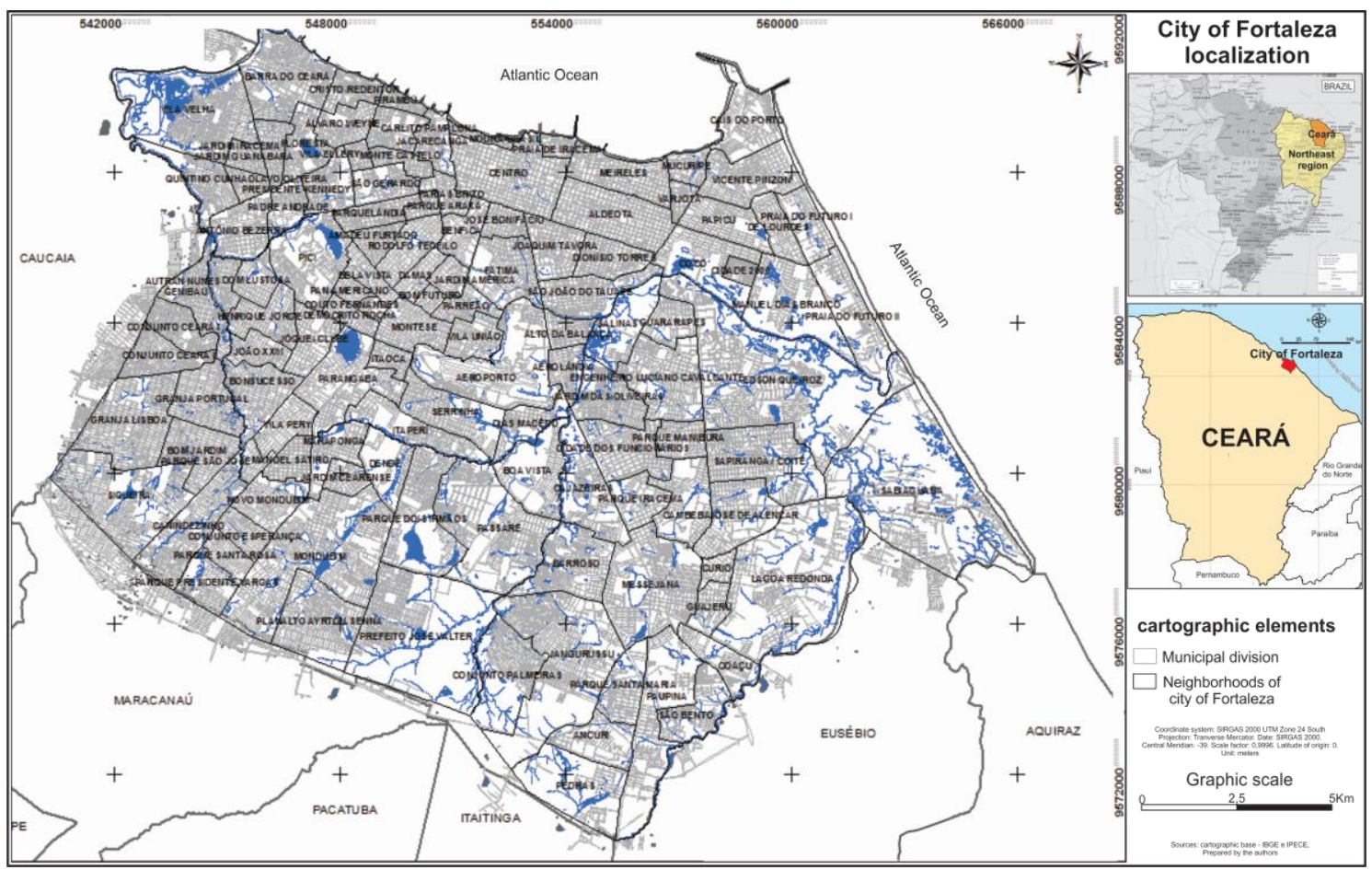

Source: Cartographic databases of IBGE and IPECE. Map produced by the authors. 


\section{METHODS}

The present study followed an integrative approach, based on the mapping and characterization of the quantitative parameters and demography of the precarious settlements, as a whole, and by type, including the number of properties, inhabitants, and families, the area (in $\mathrm{km}^{2}$ ), population density, and the density of properties. The different types of precarious settlement were also mapped within the municipality of Fortaleza.

The analyses included a conceptual literature search, the analysis of documentary evidence, and technical visits in the field. These data were integrated and summarized by basic and thematic mapping, using remote sensing data and geoprocessing techniques for the identification, location, delimitation, and classification of the different types of settlement. The number and density of inhabitants, families, and properties were also estimated.

The principal data used in the present study were the official information provided by the Fortaleza Municipal Council through the reports of the Municipal Finance Secretariat (SEFIN), the Municipal Housing Development Secretariat (HABITAFOR), and the Municipal Civil Defense Coordination, COMDEC (Table 2). Data were also obtained from the Ceará state government, primarily from the Housing Master Plan developed by the Secretariat for Local and Regional Development in 2003. Data from federal sources included those from the Brazilian Institute for Geography and Statistics (IBGE) and the Ministry for Cities, through the João Pinheiro Foundation and the Center for Metropolitan Studies (CEM).

Table 2: Precarious settlements - Sources of data

\begin{tabular}{|c|c|c|c|}
\hline $\begin{array}{c}\text { Type of } \\
\text { precarious } \\
\text { settlement }\end{array}$ & Theme & Source & Organ \\
\hline All & Precarious settlements & Fortaleza (2012) & HABITAFOR \\
\hline \multirow{3}{*}{$\begin{array}{c}\text { Shanty- } \\
\text { towns }\end{array}$} & Density of shanty-towns & Fortaleza (1997) & COMHAB \\
\cline { 2 - 4 } & Subnormal settlements & Fortaleza (2002) & PMF \\
\cline { 2 - 4 } & Precarious settlements & Ceará (2003) & Government of Ceará/SDLR \\
\cline { 2 - 4 } & $\begin{array}{c}\text { Settlements in river beds, areas } \\
\text { belonging to institutions and on } \\
\text { public land }\end{array}$ & Fortaleza (2010) & SEFIN \\
\cline { 2 - 4 } & Areas of risk in Fortaleza & Fortaleza (2011) & COMDEC \\
\hline \multicolumn{2}{|r|}{ Tenements in the city center } & Fortaleza (2009) & HABITAFOR \\
\hline \multicolumn{2}{|r|}{ Community housing projects } & Fortaleza (2010) & Ceará (2003), Fortaleza (2002 and 2012). \\
\hline \multicolumn{2}{|c|}{ Housing estates } & & \\
\hline
\end{tabular}

Source: organized by the authors.

The precarious settlements were mapped using a Geographic Information System (GIS), integrated with a geographic database, together with a set of information that characterizes each settlement. The data obtained from different sources, and in different formats, were standardized and converted into shapefile format in the UTM projection system, zone 24 South, and referenced in the SIRGAS 2000 Datum.

The mapping was based on the spatial parameters defined by the existing data, together with surveys of the new settlements, which were ultimately classified by settlement type. This classification was consolidated by a morphological analysis of a mosaic of orthophoto maps, with a $15 \mathrm{~cm}$ spatial resolution, derived from the aerophotogrammetric coverage of 2009.

The GIS database was configured in order to provide details on the general context, location, demographic diagnosis, physical structures (urban infrastructure and buildings), environmental and urban conditions, socio-economic profile, and land ownership. 


\section{RESULTS AND DISCUSSION}

\section{Precarious settlements in the Fortaleza City: from the origin of the problem to the current situation}

The establishment of precarious settlements in Fortaleza is related to the recent uncontrolled increase in population density, and is characterized by a large number of precarious buildings located in peripheral zones and areas of reduced value on the formal property market. Population growth, stimulated by the rural-urban exodus of the early 20th Century, which intensified in the 1930s, was identified by Silva (2009) as one of the fundamental sources of the problem, leading to the formation of nuclei of precarious housing, with negative effects on the administration of the city's real estate.

The population of Fortaleza continued to grow rapidly in the 1940s, leading to grave social problems and precarious living conditions. The resulting shanty-towns were populated by needy, unemployed or subemployed inhabitants, mostly immigrants (SOUZA, 2009).

Most of the shanty-towns in Fortaleza were established and consolidated during the first half of the 20th Century, and have grown continuously since this time, as shown by Braga (1995), who analyzed the city's housing problems through the assessment of the communities of Pirambu, Poço da Draga, Cinzas, Lagamar, located near the center of the city and the principal zones of employment. The shanty-towns of Fortaleza were consolidated in the 1950-60s, as a result of the exclusionary property structure of the state of Ceará, which intensified during periods of drought and the growth of the industrial labor market, that created strong incentives for the exodus of rural populations to the city.

During the 1970s and 1980s, shanty-towns expanded towards the periphery of Fortaleza (PEQUENO, 2008), through the creation of new settlements, the expansion of existing settlements, and the verticalization of constructions. In the 1990s, the shanties began to encroach more fragile environments, creating areas of risk, exacerbating both housing and environmental problems.

Historically, shanty-towns are the most common type of precarious settlement in Fortaleza. The available data show an increase in their growth from the 1970s, intensifying the trend observed since the 1930s. Between 1973 and 2011, the number of shanty-towns/communities in the Fortaleza City increased almost sixfold, from 120 to 619. It is important to remember, however, that the various studies are based on different methods, and vary in the way shanty-towns are defined, especially by the state government.

In the 1970s, 120 shanty-towns were identified in the Fortaleza City. By the beginning of the 1980s, 224 communities of this type were identified, rising to 355 by the 1990s. In 2000, the number of shanty-towns reached 614, and in 2011, 619 (Table 3).

The official IBGE data from 2000 show a total of 611,112 inhabitants living in shanty-towns, representing $28.67 \%$ of the city's population. This type of settlement was distributed throughout the city, from the coastline to the urban periphery (BRASIL, 2001, 2007). In 2010, IBGE adopted a different approach, based on the refinement of the definition of the types of settlement, which included categories such as shantytown, irregular allotment, grotto, lowland, community, neighborhood, "mocambo", and stilt housing, for example. This resulted in a reduction in the absolute number of shanty-towns recorded in the survey in comparison with the preceding decade. In this case, a total of 509 shanties were censused in Fortaleza, with 396,370 inhabitants, $16.2 \%$ of the population of the city. A number of researchers and institutions have collected data on the shanty-towns of the Fortaleza City, based on a range of different criteria (summarized in Table 3).

Table 3: Shanty-towns in the Fortaleza City between 1973 and 2011

\begin{tabular}{|c|c|c|c|}
\hline Year & $\begin{array}{c}\text { Number of shanty- } \\
\text { towns }\end{array}$ & Population & Source \\
\hline 1973 & 120 & No data & Souza (2013) \\
\hline 1981 & 244 & 330.825 & Silva (2009) \\
\hline 1990 & 355 & No data & Fortaleza (1997) \\
\hline 1991 & 341 & 108.000 & Pequeno (2008) \\
\hline 1999 & 434 & 653.670 & CDPDH (2000) \\
\hline 2000 & 614 & 759.000 & CDPDH (2000) \\
\hline 2002 & 600 & 150.000 & Pequeno (2008) \\
\hline 2010 & 509 & 396.370 & IBGE (Brasil, 2011) \\
\hline 2011 & 619 & No data & Souza (2013) \\
\hline
\end{tabular}

Source: Organized by the authors. Note: includes only sources that provide quantitative data on the shanty-towns during the respective period. 
Shanty-towns were distributed throughout a number of different areas of the Fortaleza City during the 20th Century, independently of the economic conditions of the housing market (PEQUENO, 2008; SOUZA, 2009; SOUZA, 2013). The data also reveal an exponential growth in the numbers of households and their population at the beginning of the 21st Century, with increasing rates of cohabitation and the density of properties, with land being used more intensively, and buildings growing vertically. The expansion towards the periphery and neighboring municipalities (metropolitan slums) is increasingly evident, as is the differentiation of the settlements according to the location within the city and the increasing internal diversity of each settlement.

The progressive occupation of Areas of Permanent Protection, or APPs (a federal category of protected area), the high proportion of rented or loaned households, which reflects the residential mobility of the inhabitants, and the growth of an informal property market were highlighted by Gondim (2010), who concluded that Fortaleza may have exhausted the potential areas for expansion, leading to the increasing occupation of areas unsuitable for housing. The ongoing growth in the demand for housing and the progressively harsher socio-economic conditions make the formal housing market increasingly inaccessible, especially in the absence of any effective public housing policy. This process has also led to a marked growth in environmental problems through the occupation of increasingly fragile areas, aggravating situations of socio-environmental risk (SANTOS, 2015).

The available studies of the housing problems of Fortaleza related to the establishment of precarious settlements at the end of the 20th Century and beginning of the 21st Century focus primarily on the shanty-towns, although it is important to include other types of settlement, given the complexities of the question, above all, differences in the vulnerability of the different types of housing, and potential measures for the reduction of the risk of disasters.

\section{Current situation of the precarious settlements in the Fortaleza City}

The findings of the present study provided a database for the mapping of the different types of settlements in the Fortaleza City (Figure 3). The settlements were classified as shanty-towns, irregular allotments, community housing projects or housing estates.

Figure 3: Fortaleza City - different types of precarious settlement.

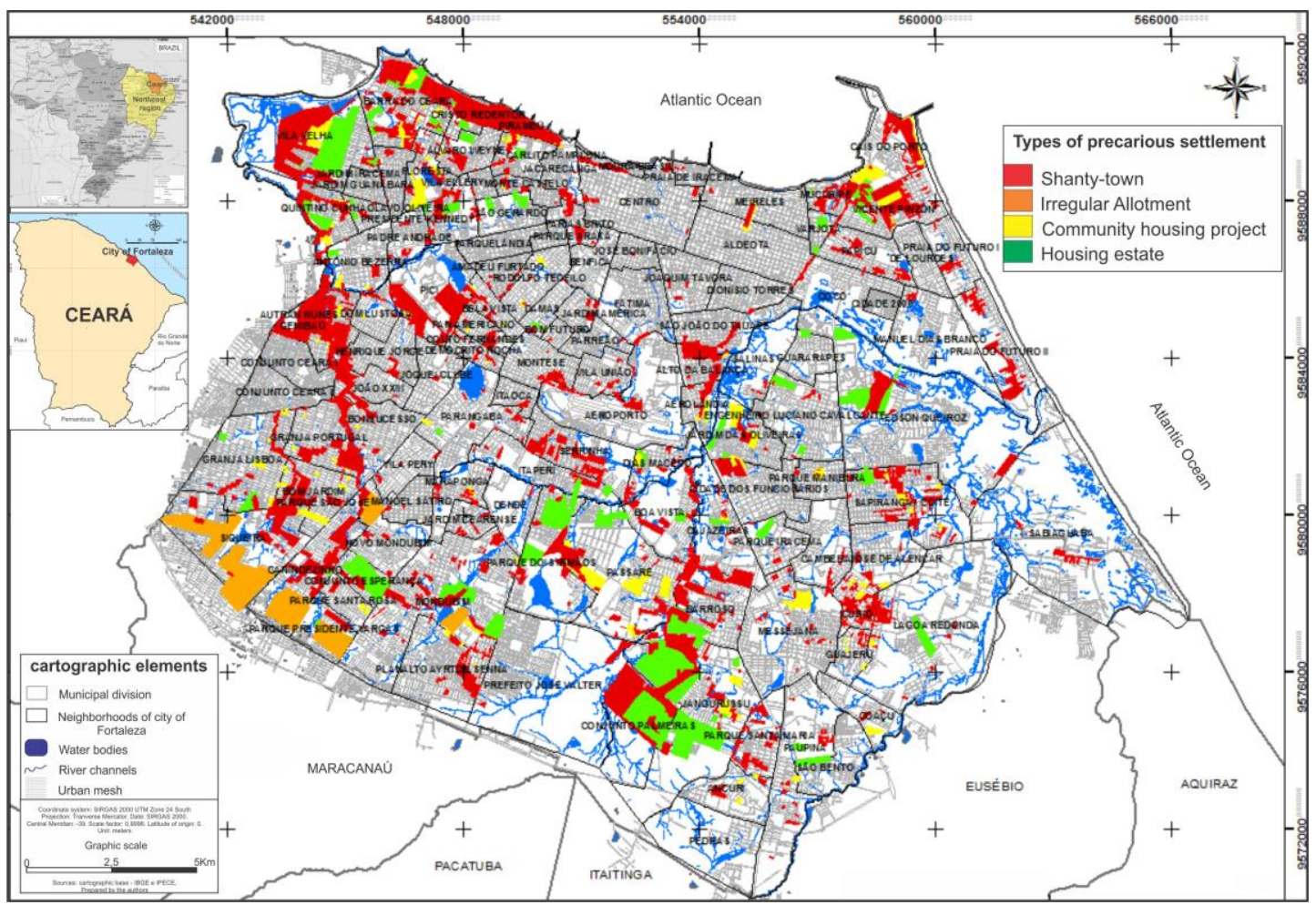

Source: Cartographic databases - IBGE and IPECE. Elaborated by the authors. Note: the different types of precarious settlement were classified as shanty-town, irregular allotment, community housing project and housing estate. 
A total of 838 precarious settlements were identified, including 29 tenements, all located in the center of the city, 16 irregular allotments, 48 degraded housing estates, 128 community housing projects, and 617 shanty-towns (Table 4).

Table 4: Types of precarious settlement found in the Fortaleza City, and their contribution to the city's demographic landscape

\begin{tabular}{|c|c|c|c|c|c|c|c|}
\hline $\begin{array}{c}\text { Type of precarious } \\
\text { settlement }\end{array}$ & Properties & Families & Inhabitants & $\begin{array}{c}\text { Area } \\
\left(\mathrm{km}^{2}\right)\end{array}$ & $\begin{array}{c}\text { Inhabitants/ } \\
\mathrm{km}^{2}\end{array}$ & Quantity & $\%$ \\
\hline Tenement & - & - & - & - & - & 29 & 3,46 \\
\hline Housing estate & 30.785 & 44.638 & 115.020 & 5,11 & 22.509 & 48 & 5,73 \\
\hline $\begin{array}{c}\text { Community housing } \\
\text { project }\end{array}$ & 37.890 & 54.941 & 151.562 & 5.08 & 29.835 & 128 & 15,27 \\
\hline Irregular allotment & 14.197 & 20.586 & 56.788 & 5,58 & 10.177 & 16 & 1,91 \\
\hline Shanty-town & 160.298 & 232.432 & 641.192 & 25,47 & 25.174 & 617 & 73,63 \\
\hline Total & 243.170 & 352.597 & 964.562 & 41,24 & 22.509 & 838 & 100,00 \\
\hline
\end{tabular}

Source: Elaborated by the authors

A total of 243,170 properties were identified, which were occupied by 352,597 families, with a total population of 964,562 inhabitants living in precarious conditions in the city (Table 5). These settlements have a relatively large population, representing a high proportion of the municipality's lowincome social groups.

Table 5: Contribution of precarious settlements to the demographic landscape of the Fortaleza City

\begin{tabular}{|c|c|c|c|}
\hline Variable & \multirow{2}{*}{ Fortaleza } & \multicolumn{2}{|c|}{ Precarious settlements } \\
\cline { 3 - 4 } & & Total & $\%$ \\
\hline Number of properties & 710,066 & 243,170 & 34.25 \\
\hline Number of families & 700,867 & 352,597 & 50.31 \\
\hline Number of inhabitants & $2,452,185$ & 964,562 & 39.34 \\
\hline Area in km ${ }^{2}$ & 314.9 & 41.24 & 19.19 \\
\hline Population density (inhabitants $/ \mathrm{km}^{2}$ ) & 7786.52 & 23,389 & - \\
\hline Density of properties (properties $/ \mathrm{km}^{2}$ ) & 2254.9 & 5896.5 & - \\
\hline
\end{tabular}

Source: Brasil (2011) and present study. Organized by the authors. Note: These data do not include the demography of the tenements due to the lack of data in the source consulted: Housing Plan for the Rehabilitation of central Fortaleza-PHRACF (Fortaleza, 2009).

Based on the results of the present study, the inhabitants of the precarious settlements represent $39.34 \%$ of the total population of Fortaleza. The settlements also include more than a third $(34 \%)$ of all the households in the city, and together occupy $19.19 \%$ of its area total, with a total of $41.24 \mathrm{~km}^{2}$ and a built-up area of $35.35 \mathrm{~km}^{2}$. The population density is 23,389 inhabitants $/ \mathrm{km}^{2}$, with 5896.5 properties per $\mathrm{km}^{2}$. These high densities contribute to the excessive demand on infrastructure and services, which are typically deficient, as well as enhancing socio-environmental risks.

The 29 tenements identified in the Centro neighborhood correspond to $3.5 \%$ of the total of precarious settlements found in Fortaleza. The principal problem of the tenements in Fortaleza is their high population density and lack of public sanitation, which is reflected in the risk of epidemiological outbreaks. This clandestine housing system operates with no official authorization or regulation. Tenements are also found in a number of neighborhoods outside the center of the city, and are hidden within the spatial context of the communities, which makes it almost impossible to identify them without fieldwork on a local scale.

The 48 degraded housing estates correspond to $5.7 \%$ of the precarious settlements of the Fortaleza City. These estates contain 115,020 inhabitants in 44,638 families, occupying 30,785 properties, and present the best housing conditions of any of the precarious settlements found in the city. The problems are related principally to the poor conditions and lack of maintenance of the buildings. The precariousness of this housing is exacerbated by the unregulated property ownership. These settlements typically have properties with a minimally adequate structure, as well as access to urban infrastructure and public sanitation (Figure 4).

$\begin{array}{llllll}\text { Caminhos de Geografia } & \text { Uberlândia - MG } & \text { v. 19, n. } 67 & \text { Set/2018 } & \text { p. 289-303 } & \text { Página } 297\end{array}$


Figure 4: Fortaleza City - degraded housing estates.

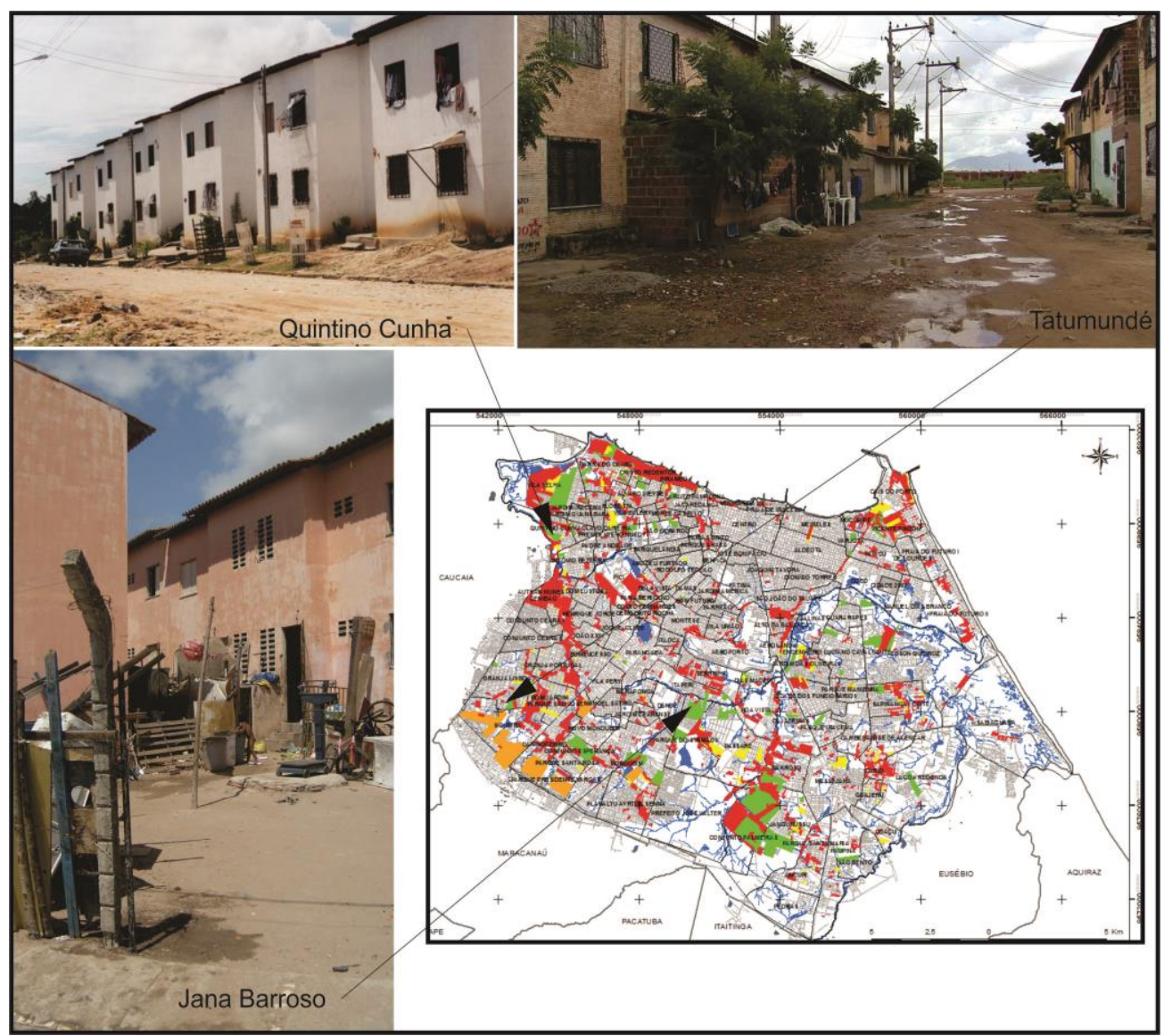

Source: Authors.

While these estates are distributed throughout the municipality, they are concentrated in the northwestern portion of the city, in the region of Barra do Ceará and Vila Velha, as well as the centralsouthern portion, in Grande Jangurussu. This type of settlement is completely absent from the central neighborhoods of the city, however.

The community housing projects bear a number of similarities with the housing estates, although they are horizontal developments, composed of single-family, terraced houses with backyards. There is no collective administration, however, or community organization.

The 128 community housing projects identified in the present study correspond to $15.27 \%$ of the precarious settlements in Fortaleza, with a total population of 151,562 inhabitants, distributed in 54,941 families occupying 37,890 properties. These projects are derived from state and municipal housing programs, which follow a standardized approach to the production of the houses through a partnership between the public administration and the candidate families. The public institution responsible for the program register and select the families with the participation of local community leaders, and are responsible for the architectural projects and urban planning, technical social work, the system of urban infrastructure and public sanitation, the building material, and the monitoring and regulation of the construction. The families selected for the program are responsible for labor, which is generally communal and cooperative, based on mutual assistance. The lack of property regulation, subsequent building activities, and the deficient maintenance of the systems of infrastructure contribute to the illegality and inadequacy of these estates, exacerbating their precariousness (Figure 5).

These community housing projects are distributed throughout the municipality, although there are major concentrations in the northwestern portion, Barra do Ceará and the northeastern portion, near Porto do Mucuripe, in the central portion, in the Passaré, Parque Dois Irmãos, Jardim das Oliveiras and Eng. Luciano Cavalcante neighborhoods, and the southwestern portion, in the Grande Bom Jardim region. The irregular allotments are difficult to identify within the city. Most were established during the 1970s and 1980s, and were once part of the formal structure of the city, with regular urban

\begin{tabular}{llllll}
\hline Caminhos de Geografia & Uberlândia - MG & v. 19, n. 67 & Set/2018 & p. 289-303 Página 298
\end{tabular}


infrastructure, public sanitation, and essential services. A total of 16 irregular allotments, classified as precarious, were identified in the Fortaleza City. The evidence indicated that these settlements were installed relatively recently, and are recorded as unapproved in the municipal registry, and no process of registration has been opened, which reflects the clandestine nature of these settlements, which are illegally occupied and have no property regulation.

Figure 5: Fortaleza City - community housing projects.

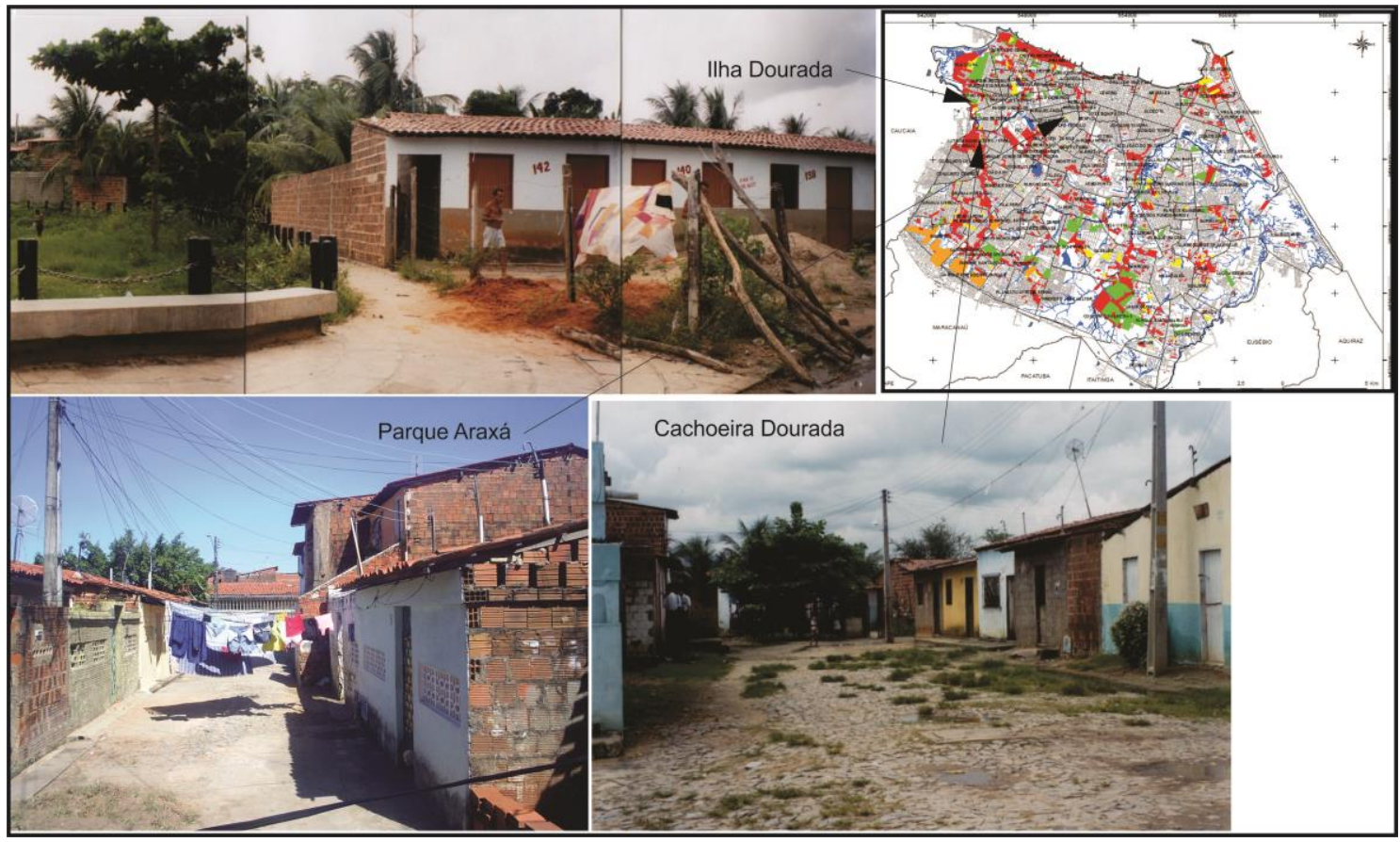

Source: Authors.

Most of the irregular allotments were found in the peripheral southwestern fringe of the city. These settlements encompass 14,197 properties occupied by 20,586 families, with a total population of 56,788 inhabitants. This category makes up $1.9 \%$ of the precarious settlements of Fortaleza, with $5.84 \%$ of the properties, which cover a total area of $5.58 \mathrm{~km}^{2}$. This represents $13.5 \%$ of the area occupied by precarious settlements and $1.8 \%$ of the total area of the municipality, which has been occupied illegally.

As in the rest of Brazil, shanty-towns are the principal type of precarious settlement in Fortaleza. Following recent trends, they outstripped irregular allotments and tenements in both number and population by the turn of the 20th Century and the beginning of the 21st Century.

A total of 617 shanties were identified in the Fortaleza City in the present study. These communities are extremely diverse, with a variety of economic, social, and cultural conditions, with different types of political organization. The shanties of Fortaleza correspond to $73.62 \%$ of the city's precarious settlements, with 160,298 properties occupied by 232,432 families and 641,192 inhabitants (Figure 6 ).

Overall, $22.58 \%$ of the properties in Fortaleza are found in shanty-towns. The population of these shanties corresponds to $66.47 \%$ of the population of precarious settlements, and $26.15 \%$ of the city's population. Shanties also correspond to $61.76 \%$ of the area covered by precarious settlements, an area of $25.47 \mathrm{~km}^{2}$, corresponding to $8.1 \%$ of the municipality.

Shanties are distributed throughout the city, with major concentrations on the western coast (the region of Grande Pirambu) and the central-eastern region (Porto do Mucuripe, Morro Santa Terezinha, Castelo Encantado, and Serviluz) (Figure 7). According to the IBGE, the Grande Pirambu community was the seventh largest shanty-town in Brazil in 2011, with 42,878 inhabitants (BRASIL, 2011). 
Figure 6: Fortaleza City - shanty-towns.

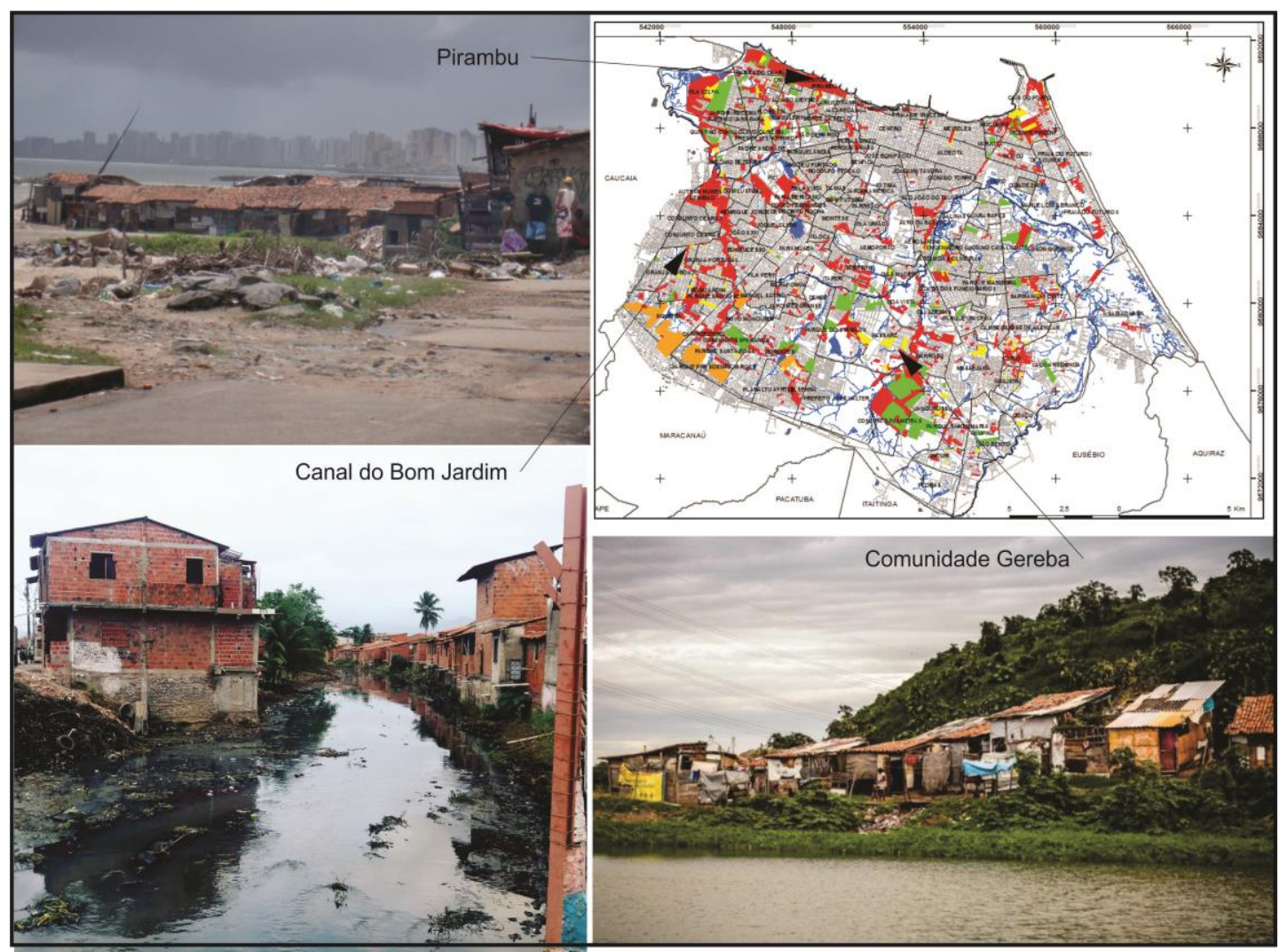

Source: Authors.

Figure 7: Fortaleza City - spatial distribution of shanty-towns.

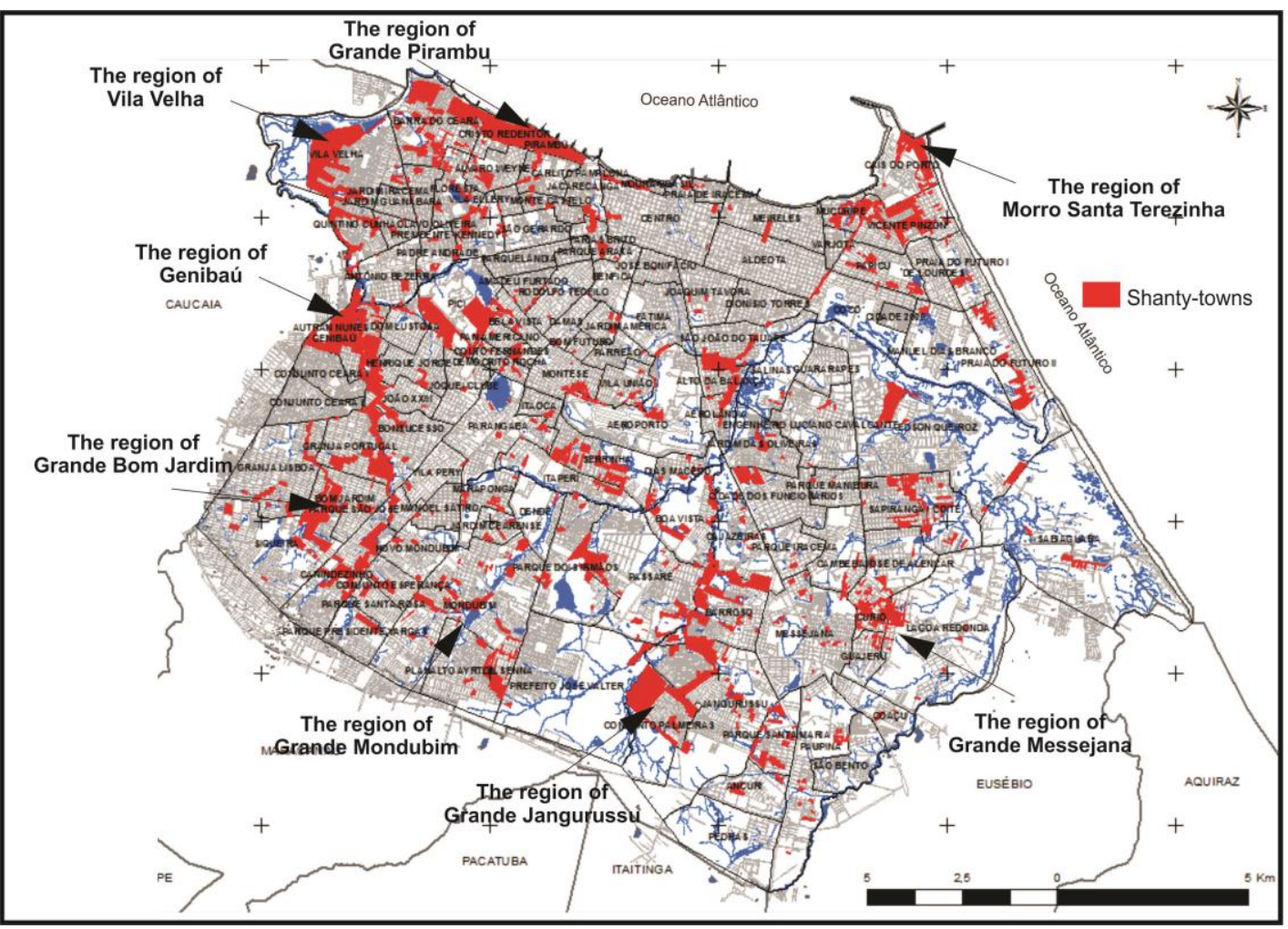

Source: Authors. 
Shanty-towns are concentrated in the fringe of the urban zone to the northwest (the region of Vila Velha and Quintino Cunha), west (Antônio Bezerra and Genibaú), southwest (Grande Bom Jardim), southeast (Grande Mondubim, Grande Jangurussu, Grande Messejana). Shanties are also concentrated along the margins of the Maranguapinho and Cocó rivers, and the many lagoons found within the city. These areas contribute to the risk of environmental disasters, given the extreme fragility of the environments and the social vulnerability of the resident communities (see SANTOS, 2015).

\section{CONCLUSIONS}

Historically, the Fortaleza City has been characterized by major socio-economic inequalities, which has resulted in a clear segregation of the social space, expressed by the qualities of the properties of the different social groups, reflecting their income levels. At the beginning of the 21 st Century, precarious settlements represent an important component of the demographic landscape of the Fortaleza City, with approximately $30 \%$ of the properties, and $40 \%$ of the population. These settlements are distributed throughout the municipality, but primarily in the areas with least infrastructure and services, and the greatest deficiencies in urban structures, whether public or private. These urban spaces are occupied traditionally by the low-income segments of the city's population.

The greatest concentrations of these settlements are found in the southern, southeastern, and southwestern sectors of the municipality, with half the total number, forming a peripheral belt of poverty characterized by a diversity of property types and styles. The central, northern, and northnortheastern neighborhoods of Fortaleza, and the geodesic center of the municipality have the lowest number of precarious settlements in comparison with other neighborhoods. The precarious settlements of the Centro neighborhood are predominantly tenements.

The results of the present study offer valuable insights into the vulnerability of the city to environmental disasters, and its relationship with other aspects of urban development policy. These insights should help comprehend the spatial relationship between the settlements and important factors such as the natural conditions of the urban area, property rights, the housing market, the involvement of popular and institutional political movements.

The current situation of the precarious settlements of the Fortaleza City, at the beginning of the 20th Century, together with the analysis of the classification and spatial distribution of the different types of settlement, provide important indices for the discussion of the problems of the urban space, in terms of social, housing, urbanization, and environmental questions. These questions should be analyzed through a multidisciplinary approach, based on geographical science, which will be fundamental to the integration of the social and natural dimensions, summarized in terms of space and territory.

\section{ACKNOWLEDGMENTS}

This study was financed by the Ceará State Research and Development Foundation (FUNCAP).

\section{REFERENCES}

BRAGA, Elza Maria Franco. Os labirintos da habitação popular: conjunturas, programas e atores. Fundação Demócrito Rocha: Fortaleza, 1995.

BRASIL. Ações integradas de urbanização de assentamentos precários. 1a edição. Edição bilíngue. Ministério das Cidades/Citties Aliance, Brasília/São Paulo, 2010a.

BRASIL. Assentamentos precários no Brasil urbano. Ministério das Cidades/Secretaria Nacional de Habitação. Centro de Estudos das Metrópoles - CEBRAP. Brasília, 2007.

BRASIL. Censo demográfico 2000. Rio de Janeiro: Instituto Brasileiro de Geografia e Estatística (IBGE), 2001. Disponível em: http://www.ibge.gov.br/home/estatistica/populacao/censo2000/

(Acessado em 02 de agosto de 2014).

BRASIL. Censo demográfico 2010. Rio de Janeiro: Instituto Brasileiro de Geografia e Estatística (IBGE), 2011. Disponível em: <http://www.ibge.gov.br/home/estatistica/populacao/censo2010/>. Acesso em: 02 de agosto de 2014. 
BRASIL. Guia para o mapeamento e caracterização de assentamentos precários. Brasília: Ministério das Cidades, 2010b.

BRASIL. Política nacional de habitação. Caderno MCidades: Habitação, n.4. Brasília: Ministério das Cidades, 2004.

CARLOS, Ana Fani Alessandri. A Cidade. 9aㅡ edição, 2ª reimpressão. São Paulo: Contexto, 2015.

CDPDH. Manual da miséria em áreas de risco. Fortaleza-Ceará-Brasil. Fortaleza: Centro de Defesa e Promoção dos Direitos Humanos da Arquidiocese de Fortaleza - CDPDH, 2000.

CEARÁ. Plano Diretor Habitacional - PDH. Fortaleza: Governo do Estado do Ceará, Secretaria do Desenvolvimento Local e Regional, 2003.

CORREA, Roberto Lobato. O espaço urbano. 4ª edição. São Paulo: Editora Ática, 1999.

COSTA, Luiz Carlos. Aspectos político-administrativos do planejamento urbano. In: Toledo, Ana Helena Pompeu de; Cavalcanti, Marly. (Org.) Planejamento urbano em debate. São Paulo: Cortez \& Moraes, 1978.

FORTALEZA. Plano Habitacional para Reabilitação da área Central de Fortaleza. Fortaleza: Prefeitura Municipal de Fortaleza, Fundação de Desenvolvimento Habitacional de Fortaleza (HABITAFOR), Piratininga, 2009.

FORTALEZA. Relatório das áreas de risco de Fortaleza - 2010. Comunicação interna da Coordenadoria Municipal de Defesa Civil/Prefeitura Municipal de Fortaleza - COMDEC/PMF. Prefeitura Municipal de Fortaleza. Fortaleza, 2011.

FORTALEZA. Plano local de habitação de interesse social de Fortaleza (PLHISFor). Fortaleza: Prefeitura Municipal de Fortaleza, Fundação de Desenvolvimento Habitacional de Fortaleza (HABITAFOR), 2012.

FORTALEZA. Síntese diagnóstica de Fortaleza. Fortaleza: Secretaria de Desenvolvimento Urbano e Infraestrutura, 2004.

FORTALEZA. Banco de dados da Secretaria de Finanças de Fortaleza - SEFIN: áreas públicas: fundo de terra; bens patrimoniais do município por usos; vias ocupadas por assentamentos. Fortaleza: Prefeitura Municipal de Fortaleza, Secretaria de Finanças de Fortaleza - SEFIN, 2010.

FORTALEZA. Plano estratégico municipal para assentamentos subnormais - PEMAS. Município de Fortaleza. 2a atualização. Fortaleza: Prefeitura Municipal de Fortaleza, Comissão de Implantação de Projetos Habitacionais de Interesse Social e Infraestrutura Urbana (COMHAB), Secretaria Especial de Desenvolvimento Urbano (SEDU). Governo Federal do Brasil, Programa Habitar Brasil/Banco Interamericano de Desenvolvimento - BID (PHBB), 2002.

FORTALEZA. Relatório das realizações da COMHAB 1990-1996. Comissão de implantação de projetos habitacionais de interesse social e infraestrutura urbana - COMHAB. Prefeitura Municipal de Fortaleza. Fortaleza, 1997. Mimeo

FUNDAÇÃO JOÃO PINHEIRO. Déficit habitacional municipal no Brasil. FJP/Centro de estatística e informações. Belo Horizonte: Fundação João Pinheiro/Centro de estatística e informações, 2013. Disponível em: <http://www.fjp.mg.gov.br/index.php/docman/cei/deficit-habitacional/216-deficithabitacional-municipal-no-brasil-2010/file>. Acesso em: 01 de agosto de 2014.

MARICATO, Ermínia. Conhecer para resolver a cidade ilegal. In: Castriotra, LB (Org.) Urbanização brasileira: redescobertas. São Paulo: Editora C/Arte, 2003. Pp. 78-96. Disponível em:

<https://erminiamaricato.files.wordpress.com/2012/09/urbanizacao-brasileira.pdf>. Acesso em: 02 de janeiro de 2015.

MARICATO, Ermínia. Informalidade urbana no Brasil: a lógica da cidade fraturada. In:

Wanderley, LE; Raichelis, R (Org.) A cidade de São Paulo: relações internacionais e gestão pública. São Paulo: EDUC, PUC-SP, 2009. Pp. 269-292. Disponível em:

<https://erminiamaricato.files.wordpress.com/2012/09/a-cidade-de-sc3a3opaulo_relac3a7c3b5esinternacionais-e-gestc3a3o-pc3bablica.pdf>. Acesso em: 02 de janeiro de 2015.

MARTINS, Maria Lúcia Refinetti. Globalização, informalidade e regulação em cidades latinoamericanas. Cadernos PROLAM/USP, n.08, p.31-50. 2006. Disponível em: <http://www.usp.br/prolam/downloads/2006_1_2.pdf >. Acesso em: 02 de janeiro de 2015.

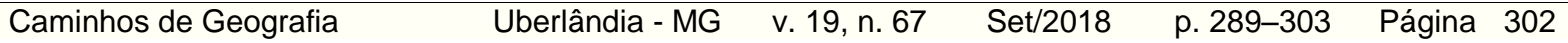


ONU-HABITAT. Estado de las ciudades de América Latina y El Caribe 2012: rumbo a uma nueva transicion urbana. Rio de Janeiro: Organización de las naciones unidas (ONU), Programa de las naciones unidas para los assentamentos humanos (ONU-Habitat), 2012. Disponível em: $<$ http://unhabitat.org/books/estado-de-las-ciudades-de-america-latina-y-el-caribe-state-of-the-latinamerica-and-the-caribbean-cities-report-espanol/>. Acesso em: 01 de agosto de 2014.

PEQUENO, Renato. Políticas habitacionais, favelização e desigualdades sócioespaciais nas cidades brasileiras: transformações e tendências. Scripta Nova: Revista Electrónica de Geografía y Ciencias Sociales. Vol. XII, 270 (35). Barcelona: Universidad de Barcelona, 2008. Disponível em: <www.ub.es/geocrit/sn/sn-270-35.htm>. Acesso em: 01 de agosto de 2014.

ROCHEFORT, Michel. Cidades e globalização. Mercator. Revista de Geografia da UFC. Ano 1, n.1 (jan./jul.2002), ano 1, n.2 (ago./dez. 2002). Fortaleza: UFC, 2002. Disponível em: <http://www.mercator.ufc.br/index.php/mercator/article/viewFile/177/143>. Acesso em: 02 de janeiro de 2015.

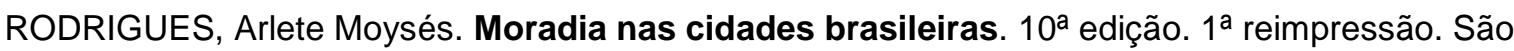
Paulo: Contexto, 2016.

SANTOS, Jader de Oliveira. Relações entre fragilidade ambiental e vulnerabilidade social na susceptibilidade aos riscos. Mercator, Fortaleza, v. 14, n. 2, p. 75-90, mai./ago. 2015. Disponível em: <http://www.mercator.ufc.br/index.php/mercator/article/viewArticle/1650>. Acesso em: 01 jan. 2016.

SANTOS, Jader de Oliveira; ROSS, Jurandyr L.S. Fragilidade ambiental urbana. Revista da ANPEGE, v.8, n.10, p.127-144, ago./dez. 2012. Disponível em: <http://anpege.org.br/revista/ojs2.4.6/index.php/anpege08/article/view/260/RA10txt09>. Acesso em: 02 de janeiro de 2015.

SANTOS, Milton. A urbanização brasileira. 5ª . Edição, 1ำ reimpressão. São Paulo: Editora da Universidade de São Paulo, 2008. 176p.

SILVA, José Borzachiello da. Formação socioterritorial urbana. In: DANTAS, Eustógio Wanderley Correia; SILVA, José Borzacchielo da; COSTA, Maria Clélia Lustosa. (Org.). De cidade à metrópole: (trans)formações urbanas em Fortaleza. Fortaleza: Edições UFC, 2009. Pp. 87-142. Disponível em: <http://www.ppggeografia.ufc.br/images/cidadeametropole.pdf>. Acesso em: 01 de agosto de 2014.

SOJA, Edward W. Geografias pós-modernas: a reafirmação do espaço na teoria social. Tradução (da $2^{a}$ edição inglesa), Vera Ribeiro; revisão técnica, Bertha Becker, Lia Machado. Rio de Janeiro: Jorge Zahar ed., 1993.

SOUZA, Maria Ângela de Almeida. O que revelam os novos levantamentos sobre a favelização nas metrópoles do Nordeste: Recife, Fortaleza, Natal e Maceió? In: Encontros Nacionais da ANPUR 15, Recife-PE, 2013. Anais... Recife. Disponível em:

<http://unuhospedagem.com.br/revista/rbeur/index.php/anais/article/view/4689/4556>. Acesso em: 02 de janeiro de 2015.

SOUZA, Maria Salete de. Análise da estrutura urbana. In: Dantas, EWC; Silva, JB; Costa, MCL. (Org.). De cidade à metrópole: (trans)formações urbanas em Fortaleza. Fortaleza: Edições UFC, 2009. Pp.13-86. Disponível em: <http://www.ppggeografia.ufc.br/images/cidadeametropole.pdf>. Acesso em: 01 agosto de 2014.

UN-HABITAT. Slums of the world: the face of urban poverty in the new millennium? London: United Nations Human Settlements Programme (UN-Habitat), Earthscan, 2003. Disponível em: $<\mathrm{http} / / /$ mirror.unhabitat.org/pmss/listltemDetails.aspx?publicationID=1124>. Acesso em: 02 de janeiro de 2015.

Recebido em: 29/05/2017

Aceito para publicação em: 26/09/2018 